\title{
Breaking the Formula in Mother--Daughter Relationship with Reference to Geetanjali Shree's Mai
}

\author{
S.Hepsiba
}

\begin{abstract}
The novel depicts how Sunaina grows up in a North Indian middle-class family under the tender care of her mother. The daughter belatedly recognizes her mother's role in creating a fertile space of freedom in which she could cultivate herself despite the stifling patriarchal environment into which she was born. Sunaina also reevaluates her mother's silence as a subtle effort to protect her against the stringencies of the society. Thus, the text exposes the rigid system that frames women within domestic confines but in doing so, advocates for borderline sites where women manifest themselves. Outlining the tradition and custom Mai stands for how the stereotype of womenhood is gradually changed through these three generation women.
\end{abstract}

Keywords: Women, Stereotype, Mother-Daughter Relationship

\section{INTRODUCTION}

Geetanjali Shree, novelist and short story writer, lives in Delhi. She is the author of several short stories and three novels. She has also written a critical work on Premchand. 'Mai' one of her three novels was short listed for the Crossword Book Award in 2001. She spent a large part of her childhood in the eastern Indian state of Uttar Pradesh. Though she writes mainly in Hindi, her works are translated into many languages. Her personal experience with the people and environment is reflected in her writing. Most of her characters mirror women's life in the conservative society.

\section{GENDER INEQUALITY}

\section{A. Conservative Indian Society}

In the conservative Indian society women are considered to be the weaker sex and they are forced to depend on a male fraternity like father, husband, and son in each stage of their life. A boundary has been fixed for women in the name of custom and tradition. One can see these elements clearly in Mai. The characters of Mai are a lively portrayal of

gender inequality, quest for freedom, suppression of women in a north Indian family. The traditional women like Dadi and Mai habituated to depending on others and to live for the members of their family, but the modern generation like Sunaina wants to grow their way but the way the society expects them to. They want to uproot themselves and grow in an independent way they wish themselves to be.

\section{B. Mai, the Mother}

Mai is written in a simple way. It deals with the life of three generation women and men. The story has Mai, the mother

Revised Manuscript Received on December 20, 2019.

S.Hepsiba* Department of English, Kalasalingam Academy of Research and Education, Srivilliputhur, India,Email: hepsibamanick@gmail.com and second generation woman as the centre. The story is narrated as events, which is seen through the daughter, the third generation woman. Mai has the diplomatic nature. She puts herself voluntarily into the pardha of old customs and traditions but helps her children from falling into it. She helps her children Subodh and Sunaina to grow in the independent way they wish. She treats both her children as same. She often get scolding from her father in law, mother in law and husband for not looking after her children and being the reason for them going in a wrong way.

\section{Sunaina's fire for breaking the sterotype}

Sunaina never seen the fire of coming out of the pardha (conservative customs) in Mai, but she felt safe behind her, she acknowledges that Mai's fire went inwards and mine outwards. But, there was a fire in both of us, that made me live peacefully with her. It's obvious in this novel how Mai's inward quest for freedom helps her daughter outward to have the equal rights. Though Mai is the typical example of women stereotype, she never allowed her daughter to become one and helped her to break the stereotype in her. From the childhood Sunaina has been helped by her mother from dragged into the so called male chauvinist society and its custom that prevents women's rights and equality.

Sunaina, the third generation woman has the traces of stereotype in her early years of growing but she had an ultimate aim of getting herself out of the house which she felt as suffocating. She doesn't like herself to become another Mai (her mother) or Dadi (grandma), the stereotype women. She wants to enjoy the rights like her brother Subodh. She hates the caution given by the elders like it is not safe outside. She asks herself, if it is being safe for Babu, Dada and Subodh, why not for me and why not for Mai also. She never had the courage to ask such questions to anyone. So, she ends up crying to herself, a common weakness of women. Throughout the novel we could see, she ended up crying in the matters she wished to get angry. In all these situations, Mai has been a backbone to her. Many a time Mai is the one who saved Sunaina from falling into the pit by throwing herself as ladder. In her childhood when she was considered as unholy because of her physical maturity during Navaratra function, Mai came and stand by her side and says to Bua "Bibiji, let the child be child" (Mai p.47)and she made her stand on feet and did the pooja. Mai never forced her to do anything. Mai helped her to get a science group against everyone's wish to make Sunaina take up arts.

\section{The Relationship between Mai and Sunaina}

Mai knows everything about her, she was able to share everything with her. She helped her in all the things. She simply let her decide what is good for her. 
In the words of Sunaina Mai is she never blindly followed what others said. Sunaina says if Mai asked to forget it she would not have get the courage to go against her. Sunaina often trapped herself due to her weakness of being a woman; those times Mai will be there to protect her. Whenever she begins with courage, she used to end up silently as her weakness over power her.

One day, Mai had shown a bird who was trying hard to fly in one place. She says "Look, in that infinity of a sky the bird was flapping its wings without going anywhere. The whole sky was the bird's. But what use was it? What use was an empty endless sky?" (Mai p.57) Sunaina often bow her head in front of Mai and forced to respect her because she is the one who protected the strength in her. She is the one who undid her chains, let the fire of becoming independent grow in her and gave the strength. Her tireless weakness that made her fights against everyone.

The novel also shows the evolution of modernism in a middle class family, starting from the food, behavior, and customs. Dada and Dadi are shown to be more conservative; Babu and Mai are a bridge between old and modern, whereas Sunaina and Subodh stands for modernism in all the things they do. Though, many a times Sunaina has dragged by others to the pardha that gives limitations to women but she has been rescued often by Mai and Subodh. The main ambition of Subodh and Sunaina in their life is to rescue Mai from the pardha she has fixed for herself. She never fights for herself, she simply take up others decision, bent over all the time for others. She makes herself happy with kitchen, taking care of everyone at home also the people who visit their house. She never complaints about anything, she fixed her house as a boundary and never wish to come out of it. Whenever Subodh and Sunaina try to bring her out of it, they ended up frustrating themselves.

\section{E. Sunaina, the Independent Woman}

As 'Diane Mariechild's famous quote "A woman is the full circle. Within her is the power to create, nurture and transform (Goodreads)." It is obvious in this novel how Mai helps her daughter to free herself breaking the old customs and traditions. She never prevented her to do anything. She always encouraged her and supported her whenever Sunaina give up crying on to her. Mai is her guide and everything that made Sunaina flutter her wings with the strong wish not to become another Mai or Prisoner of systems. Mai is the reason for the fire that has created, nurtured and transformed Sunaina into an independent modern woman.

\section{CONCLUSION}

In general the patriarchal society women would try to confine their daughters in the four walls of home with the prior knowledge that has been thrust upon them for over centuries. Here Mai takes things in a different manner. Mai's silence, paradoxically, helps her communicate and maintain some control. When she does speak, none is able to contradict her. Initially Sunaina misunderstands Mai's silence as yielding and weakness, but as she grows up she realizes that is her way of protesting and protecting her daughter from becoming the victim of this man-made belief that the world is not a better place for women.

\section{REFERENCES}

1. Shree , Geetanjali. Mai: A Novel. Edited by Anita Anantharam Translated by Nita Kumar, New Delhi, Kali for Women, 2000.

2. " "A Quote by Diane Mariechild." Goodreads,

<www.goodreads.com/quotes/260962-a-woman-is-the-full-circle-wit hin-her-is-the>

3. Martine Hennard Dutheil de la Rochère et Anas Sareen, «Beyond Centre and Margin : (Self-)translation and the Eco-poetics of Space in Geetanjali Shree's Mai », Études de lettres, 2-3 | 2014, 379-400.

4. Gupta, Shalini. "Book Review: Geetanjali Shree's 'Mai'.” India Today, $6 \quad$ Oct. 2012, www.indiatoday.in/magazine/society-the-arts/books/story/20001127book-review-of-geetanjali-shree-mai-778508-2000-11-27.

5. Siddiqi, Shams Afif. "Like a Shadow." Telegraph India, Telegraph India, www.telegraphindia.com/opinion/like-a-shadow/cid/1461440. 24Aug.2018

\section{AUTHORS PROFILE}

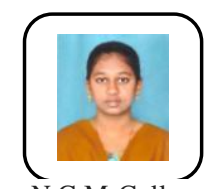

Mrs. S.Hepsiba M.A., M.Phil is a Assistant Professor in Dept. of English,Kalasalingam Academy of Research and Education, Deemed to be University, Krishnankoil, Tamilnadu. Graduating from Nallamuthu Gounder Mahalingam College,Pollachi. She did her M.Phil in N.G.M College under the guidance of Dr. Suja Mathew who had been an inspiration for her research accomplishment on Canadian writer, Yann Martel. She has presented and published many articles in literature, has attended many Workshops and Training Programmes to her credit. She has a passion for teaching literature to young minds in the pursuit of knowledge. 